\title{
Heat and Helium-3 Fluxes from Teide Volcano, Canary Islands, Spain
}

\author{
Mar Alonso (D, ${ }^{1,2}$ Eleazar Padrón, ${ }^{1,2,3}$ Hirochika Sumino, ${ }^{4}$ Pedro A. Hernández, ${ }^{1,2,3}$ \\ Gladys V. Melián, ${ }^{1,2,3}$ María Asensio-Ramos, ${ }^{1}$ Fátima Rodríguez, ${ }^{1}$ Germán Padilla, ${ }^{1,2}$ \\ Marta García-Merino, ${ }^{2}$ Cecilia Amonte, ${ }^{1}$ and Nemesio M. Pérez ${ }^{1,2,3}$ \\ ${ }^{1}$ Instituto Volcanológico de Canarias (INVOLCAN), 38320, San Cristóbal de La Laguna, Tenerife, Canary Islands, Spain \\ ${ }^{2}$ Instituto Tecnológico y de Energías Renovables (ITER), 38600 Granadilla de Abona, Tenerife, Canary Islands, Spain \\ ${ }^{3}$ Agencia Insular de la Energía de Tenerife (AIET), 38600 Granadilla de Abona, Tenerife, Canary Islands, Spain \\ ${ }^{4}$ Department of Basic Science, Graduate School of Arts and Sciences, The University of Tokyo, 3-8-1 Komaba, Meguro-ku, \\ Tokyo 153-0041, Japan
}

Correspondence should be addressed to Mar Alonso; mar@iter.es

Received 11 February 2019; Revised 22 April 2019; Accepted 14 May 2019; Published 23 June 2019

Guest Editor: Guodong Zheng

Copyright (c) 2019 Mar Alonso et al. This is an open access article distributed under the Creative Commons Attribution License, which permits unrestricted use, distribution, and reproduction in any medium, provided the original work is properly cited.

During July 2016, the first integrated heat flow, $\mathrm{CO}_{2}$, and ${ }^{3} \mathrm{He}$ emission survey was conducted across $0.5 \mathrm{~km}^{2}$ of the summit cone and crater of Teide volcano, Tenerife, Canary Islands, Spain. The thermal energy released from Teide summit cone by diffuse degassing was 2.2 MW, and the heat flux calculated through Dawson's method was 8.1 MW, difference due to the comparison of purely convective areas as the crater with diffusive areas as the flanks of the volcano. Diffuse $\mathrm{CO}_{2}$ output was $211 \pm 20 \mathrm{t} \mathrm{d} \mathrm{d}^{-1}$, and ${ }^{3} \mathrm{He}$ emission was estimated to be within a range between 0.35 and $0.89 \mathrm{~mol} \mathrm{y}^{-1}$. The obtained values of diffuse degassing and heat fluxes are close to others obtained for similar volcanic areas. The calculation of ${ }^{3} \mathrm{He} /$ heat ratio for the first time in this volcanic system supports the presence of an important mantle source for the degassing of Teide volcano.

\section{Introduction}

The Earth's mantle is an important reservoir for compounds pertinent to surface and atmospheric processes such as water, carbon dioxide, sulphur, and noble gases. Advection of heat to the atmosphere via transportation of these gases remains an understudied phenomenon despite its potential importance $[1,2]$. Volcanic activity represents focussed conduits for these fluxes and, as such, represents a key connection between the mantle and the atmosphere. Accurate measurements of both heat and gas flux from active volcanoes, and appraisal of their various sources, has contributed to a better understanding of the mantle-atmosphere link. In this study, we present the first data about the relationship between ${ }^{3} \mathrm{He}$ and heat flux in the Teide volcanic system. This work is a new contribution to ${ }^{3} \mathrm{He}$ global emission estimates.

Volcanoes emit large amounts of gases and volatiles to the atmosphere. These take the form of visible emanations through volcanic plumes, fumaroles, and solfataras and through diffuse degassing (nonvisible emanations). Both types of gas emissions are controlled by local volcanotectonic structures as a result of transport via diffusion and advection [3].

Among volcanic gases, helium has been considered as a useful tool in the geochemists' toolbox [4]. Helium is chemically inert, physically stable, nonbiogenic, sparingly soluble in water under ambient conditions, almost nonadsorbable, and, consequently, highly mobile. Due to these properties and its deep origin, helium is considered a tracer of magmatic activity and its speed of traversing the crust makes it an excellent precursor of volcanic eruptions [5-7].

There are two naturally occurring isotopes of helium: ${ }^{4} \mathrm{He}$ and ${ }^{3} \mathrm{He}$, with an atmospheric ${ }^{3} \mathrm{He} /{ }^{4} \mathrm{He}$ ratio $\left(R_{A}\right)$ of $1.384 \cdot 10^{-6}[8] .{ }^{4} \mathrm{He}$ is produced mainly in the crust as $\alpha$-particles from the radioactive decay of ${ }^{238} \mathrm{U},{ }^{235} \mathrm{U}$, and ${ }^{232} \mathrm{Th}$, while nearly all of the ${ }^{3} \mathrm{He}$ is primordial in origin and, by far, its 
most important source is the Earth's interior. The ${ }^{3} \mathrm{He} /{ }^{4} \mathrm{He}$ ratio varies from high values $\left(>10^{-5}\right)$ in mantle-derived lavas and fluids to low values $\left(\sim 10^{-8}\right)$ in continental regions [9]. Helium production and the degree of tortuosity are the main parameters that control the uprising mantle-derived helium from the source to the atmosphere, showing a decreasing trend of the ${ }^{3} \mathrm{He} /{ }^{4} \mathrm{He}$ ratio with the distance in and around stratovolcanoes $[6,10]$. However, in the case of Tenerife Island, Pérez et al. [11] demonstrated that the ${ }^{3} \mathrm{He} /{ }^{4} \mathrm{He}$ ratio remained constant regardless of the distance to Teide volcano.

In the case of the Canary Islands, the geographical distribution of the ${ }^{3} \mathrm{He} /{ }^{4} \mathrm{He}$ ratios shows the highest values on the westernmost islands (La Palma and El Hierro), which implies the existence of a helium source derived from the deep mantle [12-14]. Mass transfer of mantle helium to a fluid is accompanied by transfer of heat [15]. The presence of magmatic helium in a hydrothermal fluid therefore implies direct transport of heat from that magma to the fluid [15]. Previous studies have demonstrated a positive relation between helium isotopic composition and heat flux [16-18].

The calculated ${ }^{3} \mathrm{He} /$ heat production ratio in the upper mantle of the Earth is $\sim 0.5 \times 10^{-12} \mathrm{~cm}^{3} \mathrm{STP} / \mathrm{J}$ [19] (where STP is $P=1 \mathrm{~atm}$ and $T=25^{\circ} \mathrm{C}$ ) and is spatially heterogeneous. For instance, the ${ }^{3} \mathrm{He} /$ heat production ratio associated with hot-spot volcanism is typically $\sim 24 \times 10^{-12} \mathrm{~cm}^{3} \mathrm{STP} / \mathrm{J}$ $[19,20]$. These values are much higher than that estimated for crustal regimes, $\sim 1 \times 10^{-15} \mathrm{~cm}^{3} \mathrm{STP} / \mathrm{J}$, which are also dominated by radiogenic ${ }^{4} \mathrm{He}$ production [20]. Therefore, ${ }^{3} \mathrm{He}$ emission and heat flux studies at volcano-geothermal systems improve understanding not only of those systems but also the connection between mantle and atmosphere.

The measurement of the total thermal energy flux through the surface in volcanic areas is used to determinate changes in the magmatic activity and detecting changes in the energy balance of the volcanic system as a result of magmatic and tectonic processes [3, 21, 22].

The main objectives of this work are to compare ${ }^{3} \mathrm{He}$ emission estimated through different approaches, describe those estimates' relationship with heat flux, and calculate an indicative ${ }^{3} \mathrm{He} /$ heat production ratio at Teide volcano. It is important to highlight that it is the first study about the relationship between ${ }^{3} \mathrm{He}$ and heat flux in the Teide volcanic system. As such, this work is a new contributing value to ${ }^{3} \mathrm{He}$ global emission estimates.

\section{Geological Setting}

The Canarian archipelago is located in the Atlantic ocean about $100 \mathrm{~km}$ west of the African coast between $27^{\circ} 37^{\prime}$ and $29^{\circ} 25^{\prime} \mathrm{N}$ and between $13^{\circ} 20^{\prime}$ and $18^{\circ} 10^{\prime} \mathrm{W}$ (offshore Morocco). It consists of 7 main islands, decreasing ages from east to west, with the western islands still in the shield stage and the eastern-most in the erosional phase [23]. Their genesis continues to attract debate discussed below.

The most widely accepted "working" model is the one that combines three different hypotheses: hot spot, propagating fracture, and uplifted block hypothesis. It means that the islands originate from a thermal anomaly in the mantle helped by regional fractures for the beginning of magmatism; meanwhile, the islands are in their present freeboard attitude due to the action of tectonic forces [24].

Tenerife $\left(2,034 \mathrm{~km}^{2}\right)$ (Figure 1), the central and largest island of the archipelago, is currently at the zenith of its volcanic development $[23,25]$. The structure of Tenerife is controlled by a volcano-tectonic rift system with NW, NE, and NS directions. The oldest visible geological unit on Tenerife is called the "old basaltic series," from central Miocene, and its forms by three strongly eroded edifices distributed in the corners of the island: Anaga (north-east), Teno (north-west), and Roque del Conde (south). This unit is formed by basaltic lavas and pyroclastics with some trachytes and phonolites [26]. A period of 2-3 M.y. of volcanic quiescence and erosion took place between "old basaltic series" and the eruptions which formed the younger volcanic series. Las Cañadas volcano grew on the eroded remains of the "old basaltic series" reaching about $40 \mathrm{~km}$ in diameter and 2,700-3,000 $\mathrm{m}$ of a complex succession of basalts, trachybasalts, trachytes, and phonolites that then collapsed $200 \mathrm{ky}$ ago to form Las Cañadas caldera depression [23]. The caldera is located in the intersection of the three rifts, and the vertical collapse was associated with emptying of shallow magma chambers [27-29]. Other authors suggest the combination of vertical and lateral collapse for the formation of Las Cañadas caldera [30]. The youngest activity of the island is represented by basalts, trachytes, and phonolites of Teide-Pico Viejo volcanic complex and some individual basaltic cones scattered around the island, mainly located on the structural rift systems (NW, NE, and NS directions), characterized by the alignment of cinder cones and fissure systems, where historical eruptions occurred. Those monogenetic cones represent the most common eruptive activity during the last 1 M.y., and it is possible to easily recognize 297 of these cones in the island [31].

The $17 \mathrm{~km}$ long and $10 \mathrm{~km}$ wide caldera is the salient geomorphological feature of Tenerife partly because it hosts the highest stratovolcano in the Atlantic Ocean: Teide volcano (3,718 m.a.s.l.), a portion of Teide-Pico Viejo volcanic complex. Teide and Pico Viejo volcanoes overlap to form an elongate double cone. This volcanic complex was formed through different eruptive styles, ranging from strombolian to phreatomagmatic eruptions to cryptodome formation and dome extrusions [28, 32] forming basaltic, trachytic, and phonolitic products. The last eruption in this complex, Chahorra, occurred in 1798 through an adventive cone of Pico Viejo volcano.

Teide summit cone has been constructed during several phases. Its eruptive products are mainly phonolitic and basaltic-trachybasaltic lavas [32]. Persistent degassing activity has taken place at the summit of the volcano since the last eruption $[33,34]$.

Visible degassing in the summit cone of Teide volcano consists in low temperature fumaroles (around $83^{\circ} \mathrm{C}$ ). Water is the major component of these fumaroles, followed by $\mathrm{CO}_{2}$, $\mathrm{N}_{2}, \mathrm{H}_{2}, \mathrm{H}_{2} \mathrm{~S}, \mathrm{Ar}, \mathrm{CH}_{4}$, and $\mathrm{CO}$, a composition typical of hydrothermal fluids $[34,35]$. Diffuse degassing is the principle degassing mechanism of Teide volcano, with the highest 


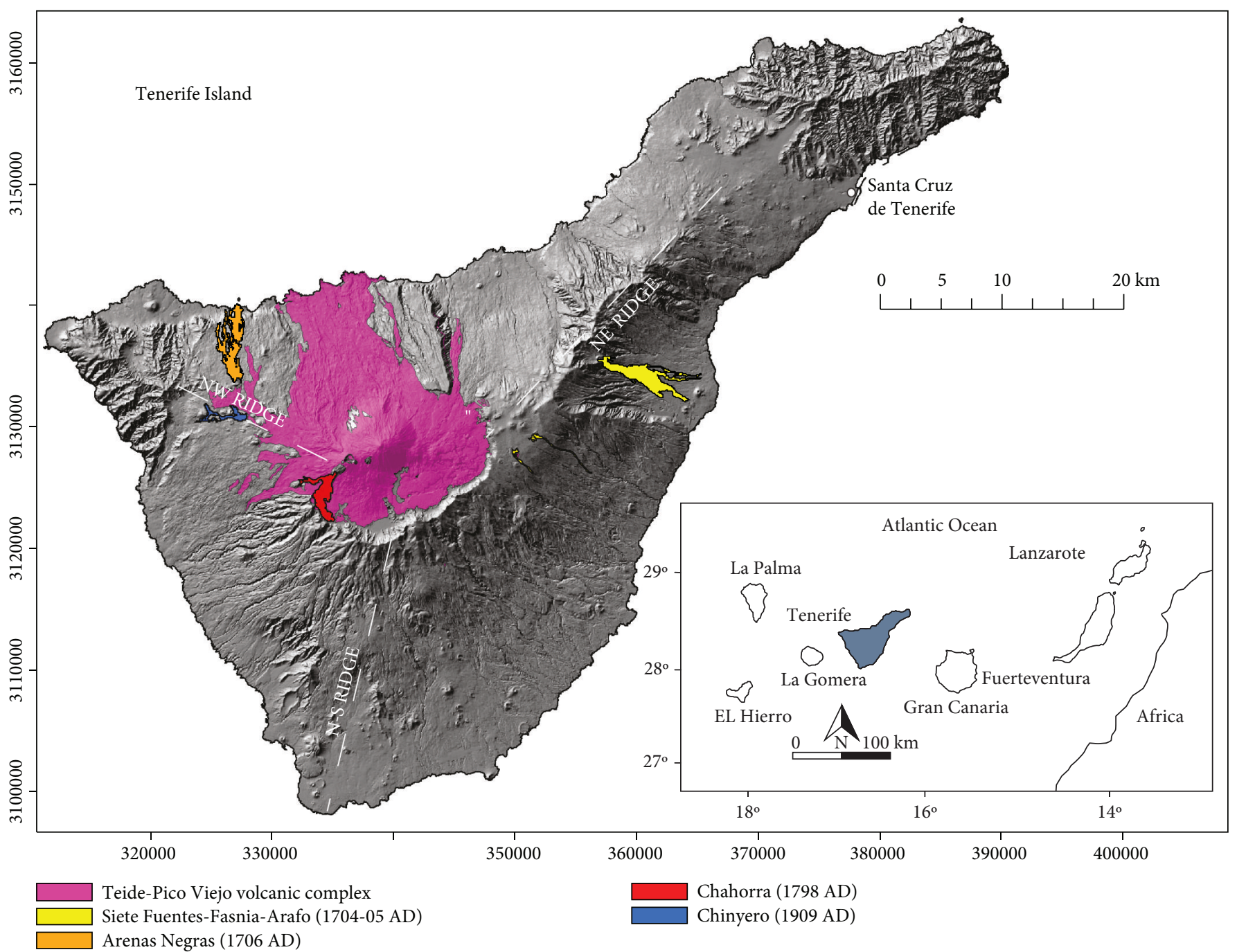

FIgURE 1: Tenerife Island marked with the location of the volcanic system studied, locations of historical eruptions and the three rifts. Inset: map of the Canarian archipelago highlighting Tenerife Island in grey.

rates emanated from the summit cone and crater of Teide volcano $[36,37]$.

\section{Sampling Procedures, Analytical Methods, and Data Reduction}

During July 2016, a soil gas survey comprised of 170 measurement sites was conducted at the summit cone of Teide volcano covering an area of $0.5 \mathrm{~km}^{2}$ (Figure 2). The field work was carried out in the summer in order to minimize meteorological influences. The average distance between points of the summit cone was 45 meters on the slopes and 10 meters inside the crater, designed to tightly constrain the areal extent of visible degassing anomalies and arrive at more accurate overall estimates, while also achieving an evenly spaced distribution per domain.

3.1. Soil $\mathrm{CO}_{2}$ Efflux and Temperature Measurements. Measurements of diffuse $\mathrm{CO}_{2}$ were conducted at the soil surface using the accumulation chamber method [38] by means of West Systems portable $\mathrm{CO}_{2}$ efflux meters equipped with a nondispersive infrared $\mathrm{CO}_{2}$ analyzer LICOR-820. This system is composed of a double beam infrared carbon dioxide sensor compensated for temperature and atmospheric pressure and an optical bench of 20,000 ppm of resolution. The gas flux meter was interfaced to a handheld computer running data acquisition software.

Soil temperature was determined by inserting a Type $\mathrm{K}$ thermocouple at each sampling site at 15 and $40 \mathrm{~cm}$ depth.

3.2. Soil Gas Sampling. At each measurement site, soil gas was collected in $20 \mathrm{cc}$ glass vials. This was achieved by inserting a $50 \mathrm{~cm}$ stainless probe $40 \mathrm{~cm}$ depth into the ground connected to a hypodermic syringe. Residual gas inside the probe was purged before sampling.

Gaseous species as $\mathrm{Ne}, \mathrm{H}_{2}, \mathrm{O}_{2}, \mathrm{~N}_{2}, \mathrm{CH}_{4}, \mathrm{CO}_{2}$, and $\mathrm{H}_{2} \mathrm{O}$ were analyzed by microchromatrography with a VARIAN model 4900 (Agilent Technologies, USA), using a thermal conductivity detector and a $20 \mathrm{~m}$ PoraPLOT Q column using argon (Ar) as carrier gas. The temperature of the column and injector was $40^{\circ} \mathrm{C}$ and $80^{\circ} \mathrm{C}$, respectively, and the injection time was $20 \mathrm{~ms}$. The detection limit for $\mathrm{CO}_{2}$ was 


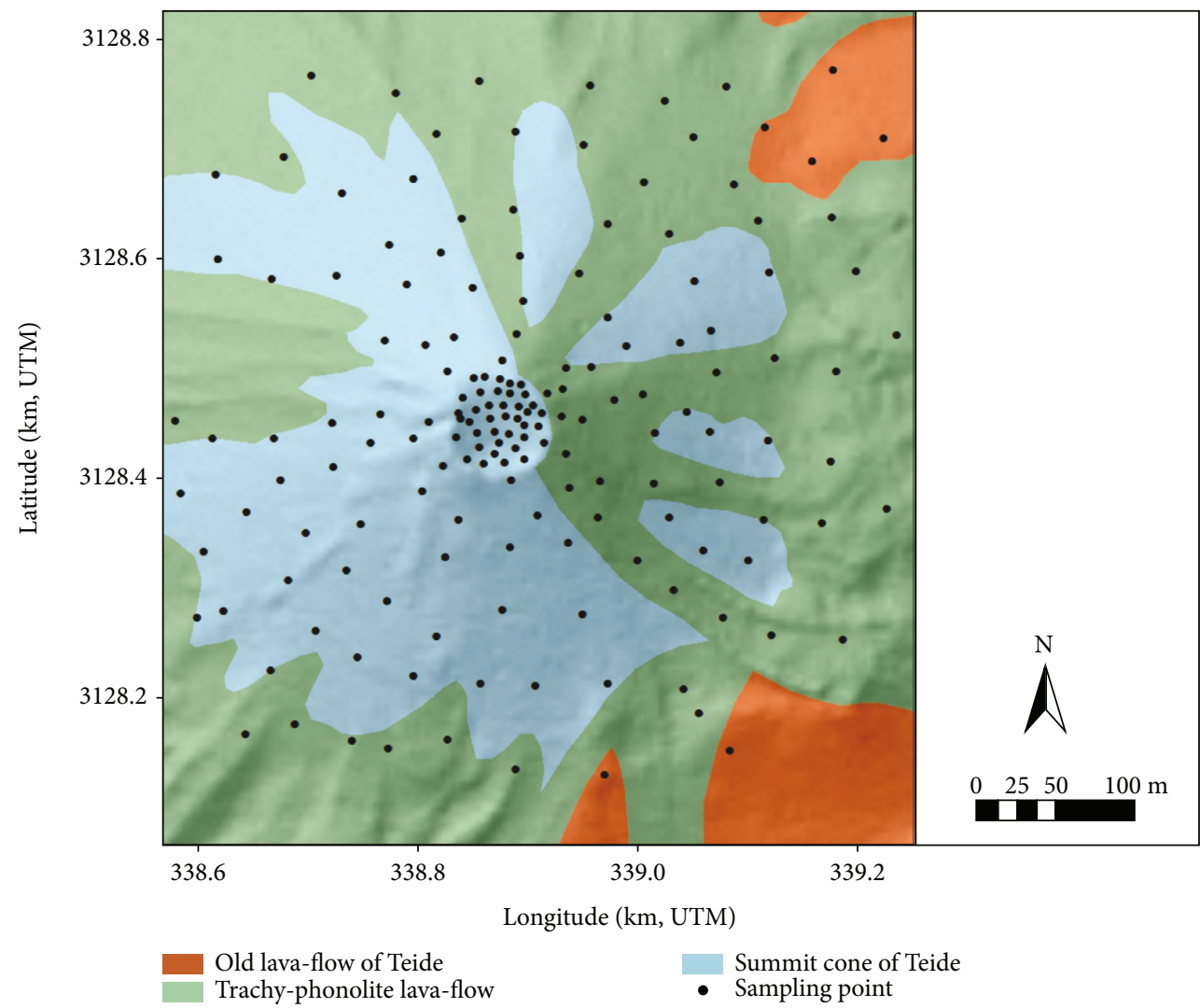

FIGURE 2: Geological map of Teide volcano summit cone and crater marked with the 170 measurement sites performed in the survey.

estimated to be about $10 \mathrm{ppmV}$, and the accuracy of the measurements was about $2.5 \%$ on the basis of standard sample measurements.

Helium was analyzed by a quadrupole mass spectrometer Pfeiffer Omnistar 422. The instrument accuracy of helium concentration was estimated to be $\pm 300 \mathrm{ppb}$, and the detection limit for helium is $1 \mathrm{ppm}$. Atmospheric gas was used periodically to calibrate the instrument.

The isotopic ratio expressed as $\delta^{13} \mathrm{C}-\mathrm{CO}_{2} \%$ vs. VPDB was measured by means of a Thermo Finnigan MAT 253 mass spectrometer. The analytical error for $\delta^{13} \mathrm{C}$ values is of $\pm 0.1 \%$.

3.3. Fumarole Sampling. Fumarolic gas samples were also collected in July 2016. Teide fumarolic activity consists of fluids discharged at approximately $83.5^{\circ} \mathrm{C}$, close to the boiling point of water at 3,718 m.a.s.l. $\left(87.5^{\circ} \mathrm{C}\right)$. A vent located inside the rim of the summit crater in the NE sector was the focus of the sampling effort.

A glass funnel was inserted into the vent and buried to prevent atmospheric air entering into the sampling system. The funnel was connected to a preevacuated glass flask filled with $50 \mathrm{ml}$ of an alkaline solution $(4 \mathrm{~N} \mathrm{KOH}) \cdot \mathrm{H}_{2} \mathrm{O}$ vapour condenses and acidic gases as $\mathrm{CO}_{2}, \mathrm{SO}_{2}$, and $\mathrm{HCl}$ dissolve into the alkaline solution, while noncondensable gases $\left(\mathrm{N}_{2}\right.$, $\mathrm{O}_{2}, \mathrm{He}, \mathrm{H}_{2}, \mathrm{CH}_{4}$, etc.) are concentrated in the gas phase of the sampling flask [35]. $\mathrm{CO}_{2}$ concentration and $\mathrm{CO}_{2} / \mathrm{H}_{2} \mathrm{O}$ molar ratio were analyzed by titration following the method described by Giggenbach and Goguel [39].
For the analysis of helium isotopes, lead-glass containers were filled with the fumarolic gas discharge. Helium concentration and ${ }^{3} \mathrm{He} /{ }^{4} \mathrm{He}$ isotopic ratios are expressed as $R_{A}=R / R_{\text {air }}$, where $R$ is the measured ${ }^{3} \mathrm{He} /{ }^{4} \mathrm{He}$ ratio and $R_{\text {air }}$ is that of the air; $1.384 \times 10^{-6}$ [8] were analyzed using a high-precision noble gas mass spectrometer (modifiedVG5400), following the procedure of Sumino et al. [40]. The correction factor for the helium isotope ratio was determined by measurements of interlaboratory helium standard named HESJ, with an established ${ }^{3} \mathrm{He} /{ }^{4} \mathrm{He}$ value of $20.63 \pm$ $0.10 R_{A}$ [41]. The analytical error for $R_{A}$ was $<2 \%$. The measured ${ }^{3} \mathrm{He} /{ }^{4} \mathrm{He}$ ratios were corrected for air contamination based on the ${ }^{4} \mathrm{He} /{ }^{20} \mathrm{Ne}$ ratios measured with the mass spectrometer, assuming that all the neon has an atmospheric origin $[16,42]$.

\subsection{Data Reduction and Spatial Interpolation}

3.4.1. ${ }^{4}$ He Flux Determination. The circulation of gases at superficial levels of volcanoes is governed by a combination of diffusive and advective mechanisms. Flows and velocities of gas moving by advective mechanisms, however, are much higher than those produced by diffusion. Diffusive and advective emission values were estimated at each sampling site as follows.

Diffusion is described by Fick's law:

$$
F_{i}=-D_{m} \frac{d C}{d z}
$$


where $D_{m}$ is the molecular diffusion coefficient $\left(\mathrm{m}^{2} \mathrm{~s}^{-1}\right)$ and $d C$ is the variation of gas concentration $\left(\mathrm{kg} \mathrm{m}^{-3}\right)$ along $d z(\mathrm{~m})$.

The apparent diffusion coefficient $(D)$ includes the effect of porosity $(n)$ and tortuosity $(\tau)$ of the environment. For soils, Etiope and Martinelli [43] define this coefficient as

$$
D=D_{m} n^{2}=D_{m} \frac{n}{\tau}
$$

Advection is described by Darcy's law:

$$
F_{i}=-C_{i} \frac{k \nabla P}{\mu Z},
$$

where $C_{i}$ is the soil gas concentration $\left(\mathrm{kg} \mathrm{m}^{-3}\right), k$ the permeability $\left(\mathrm{m}^{2}\right), \mu$ the dynamic viscosity of the gas $\left(\mathrm{kg} \mathrm{m}^{-1} \mathrm{~s}^{-1}\right)$, and $\nabla P$ the pressure difference $\left(\mathrm{kg} \mathrm{m}^{-1} \mathrm{~s}^{-2}\right)$ between two points spaced at distance $Z(\mathrm{~m})$ [43].

Soil intrinsic permeability $(k)$ is a key factor to estimate the theoretical emission of gases via Darcy's law. It depends on the hydraulic permeability $\left(K_{s}\right)$ following Schaap and Lebron [44]:

$$
k=\frac{\mu}{\rho g} K_{s}
$$

where $\mu$ is the gas viscosity $\left(\mathrm{kg} \mathrm{m}^{-1} \mathrm{~s}^{-1}\right), \rho$ the gas density $\left(\mathrm{kg} \mathrm{m}^{-3}\right)$, and $g$ the gravitational constant $\left(\mathrm{m} \mathrm{s}^{-2}\right)$.

In case of Teide volcano, pressure gradients are mostly generated by the geothermal gradient, which manifests by convection. We assume in this study, therefore, that the advective component of gas flux from the deep interior to the atmosphere is mainly governed by the efficiency of convection at the soil scale. Under this assumption, the pressure gradient is obtained from:

$$
\nabla P=P_{\mathrm{amb}}-P_{\text {soil }}=P_{\mathrm{amb}}\left(1-\frac{T_{\text {soil }}}{T_{\mathrm{amb}}}\right),
$$

where $P_{\text {soil }}$ and $P_{\text {amb }}$ are soil and ambient pressure and $T_{\text {soil }}$ and $T_{\mathrm{amb}}$ are soil and ambient temperatures, respectively.

By combining equations (3), (4), and (5), we obtain the following expression for the convective flux:

$$
F_{i}=-C_{i} \frac{K_{s} P_{\mathrm{amb}}}{\rho g Z}\left(1-\frac{T_{\text {soil }}}{T_{\mathrm{amb}}}\right) .
$$

Direct measurements of diffuse $\mathrm{CO}_{2}$ emission $\left(\mathrm{F}_{\mathrm{CO} 2}\right)$, soil $\mathrm{CO}_{2}$ concentration $\left(\mathrm{C}_{\mathrm{CO} 2}\right)$, air temperature $\left(T_{\mathrm{amb}}\right)$, and soil temperature at $40 \mathrm{~cm}$ depth $\left(T_{\text {soil }}\right)$ were used to estimate the hydraulic permeability $\left(K_{s}\right)$ from equation (6) at each sampling site. These values were used later to estimate the convective flux of ${ }^{4} \mathrm{He}$. To calculate the diffusive emission component for ${ }^{4} \mathrm{He}$, we used a $7 \times 10^{-5}$ as diffusion coefficient [43] and a value of 0.35 for porosity, as have been used in similar volcanic areas [45].
3.4.2. ${ }^{3} \mathrm{He}$ Flux Determinations. ${ }^{3} \mathrm{He}$ generally has low abundance, which leads to high analytical uncertainty for most gas samples. To arrive at an accurate estimate of flux across the study area, we must interpolate from ${ }^{3} \mathrm{He}$ measurements with high certainty using robust relationships with other gas fluxes. The ${ }^{3} \mathrm{He}$ output released to the atmosphere from the summit cone of Teide volcano can be estimated to be within the limits calculated by two end-member assumptions:

(1) $\mathrm{The}{ }^{3} \mathrm{He} /{ }^{4} \mathrm{He}$ ratio in the fumarolic gases $\left(9.34 \times 10^{-6}\right)$ is the same across the whole hydrothermal system, which is to assume the source of all helium is the same. In this case, ${ }^{3} \mathrm{He}$ emission $\left(\mathrm{mol} \mathrm{d}^{-1}\right)$ is simply calculated using the ${ }^{3} \mathrm{He} /{ }^{4} \mathrm{He}$ ratio and the ${ }^{4} \mathrm{He}$ emission $\left(\mathrm{mol} \mathrm{d}^{-1}\right)$ using the relationship:

$$
\Phi_{3 \mathrm{He}}=\left({ }^{3} \mathrm{He} /{ }^{4} \mathrm{He}\right) \times \Phi_{4 \mathrm{He}}
$$

(2) The ${ }^{3} \mathrm{He}$ flux is wholly derived from deep-seated source and therefore can be tied to the nonbiogenic component of the $\mathrm{CO}_{2}$ flux. The estimated diffuse $\mathrm{CO}_{2}$ emission, the $\mathrm{CO}_{2} /{ }^{4} \mathrm{He}$ molar ratio, and the ${ }^{3} \mathrm{He} /{ }^{4} \mathrm{He}$ isotopic ratio measured in the fumarolic discharges of Teide can be used to estimate ${ }^{3} \mathrm{He}$ output using the relationships:

$$
\begin{aligned}
\left(\mathrm{CO}_{2} /{ }^{4} \mathrm{He}\right) /\left({ }^{3} \mathrm{He} /{ }^{4} \mathrm{He}\right) & =\mathrm{CO}_{2} /{ }^{3} \mathrm{He} ; \\
\Phi_{3 \mathrm{He}} & =\Phi_{\mathrm{CO}_{2}} /\left(\mathrm{CO}_{2} /{ }^{3} \mathrm{He}\right)
\end{aligned}
$$

3.4.3. Heat Flow. $\mathrm{CO}_{2}$ was used as a tracer of hydrothermal fluids to calculate the heat flow involved in the diffuse degassing process. Chiodini et al. [46] first demonstrated this method that rests on the assumption that the $\mathrm{H}_{2} \mathrm{O} / \mathrm{CO}_{2}$ ratio is recorded, before steam condensation, by fumarolic effluents. These authors computed the heat flux adding the following contributions: (1) the heat released by $\mathrm{H}_{2} \mathrm{O}$ gas moving from the hydrothermal reservoir to the steam condensation zone, (2) the heat given off by $\mathrm{CO}_{2}$ passing from the hydrothermal reservoir to atmospheric conditions, (3) the enthalpy of steam condensation at $100^{\circ} \mathrm{C}$, and (4) the heat loss by liquid water on cooling from $100^{\circ} \mathrm{C}$ to the average seasonal value.

In the July 2016 survey, the measured $\mathrm{H}_{2} \mathrm{O} / \mathrm{CO}_{2}$ ratio was 2.24. On the basis of this ratio, we computed that $473 \mathrm{t}$ $\mathrm{d}^{-1}$ of steam are condensed to produce the hydrothermal $\mathrm{CO}_{2}$ output of $211 \mathrm{t} \mathrm{d}^{-1}$ following the procedure described by Frondini et al. [47]. The released thermal energy associated with the condensation of $473 \mathrm{t} \mathrm{d}^{-1}$ of steam was estimated on $1.26 \times 10^{12} \mathrm{~J} \mathrm{~d}^{-1}$.

This value was obtained following two contributions. The enthalpy of steam condensation at $100^{\circ} \mathrm{C}\left(1.07 \times 10^{12} \mathrm{~J} \mathrm{~d}^{-1}\right)$ is given by the product of the total amount of steam condensed in one day $\left(4.73 \times 10^{8} \mathrm{~g}\right)$ times the enthalpy of evaporation at $100^{\circ} \mathrm{C}\left(2,257 \mathrm{~J} \mathrm{~g}^{-1}\right)$ [48]. The heat loss by liquid water on cooling from $100^{\circ} \mathrm{C}$ to the average seasonal value of $3.2^{\circ} \mathrm{C}$ $\left(1.89 \times 10^{11} \mathrm{~J} \mathrm{~d}^{-1}\right)$ is given by the product of the enthalpy lost 


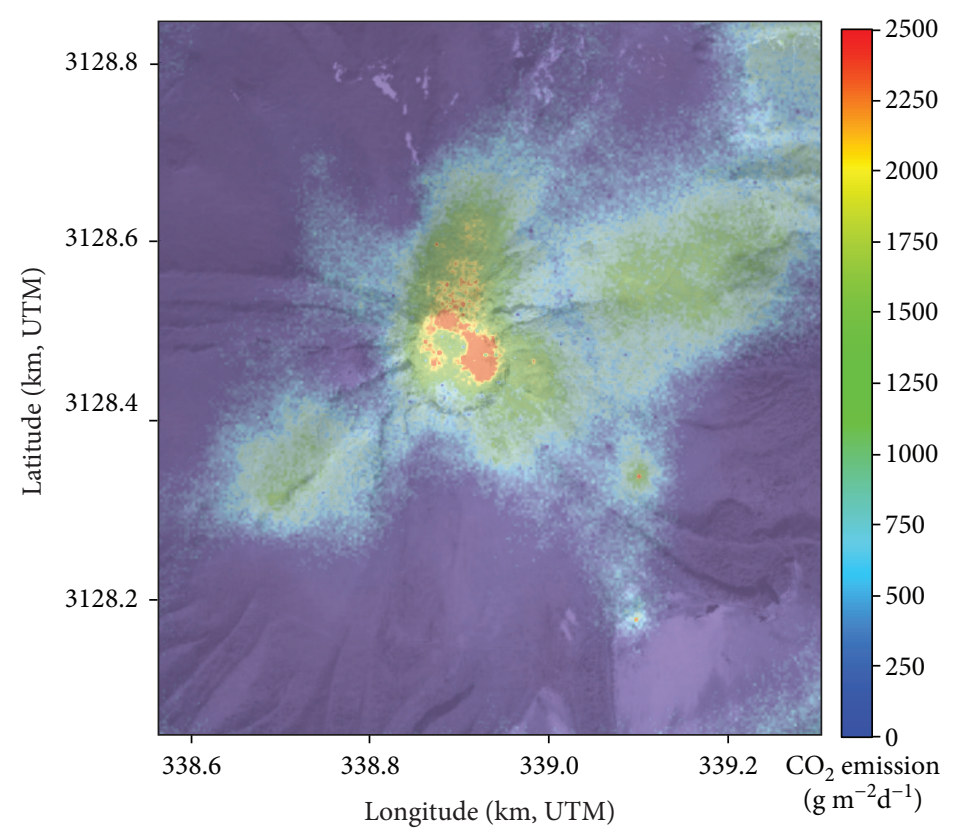

FIgURE 3: Diffuse $\mathrm{CO}_{2}$ emission map of the summit cone and crater of Teide volcano.

by $1 \mathrm{~g}$ of water $\left(\Delta \mathrm{H}=398.7 \mathrm{~J} \mathrm{~g}^{-1}\right)$ times the mass of water $\left(4.73 \times 10^{8} \mathrm{~g}\right)$.

The heat flux was also calculated following the method described by Dawson [49]. The method is based on correlation between soil temperature at $15 \mathrm{~cm}$ depth $\left(t_{15}\right)$ and surface heat flux $(q)$ by the following equation:

$$
q=5.2 \times 10^{-6} t_{15}^{4}
$$

where $t_{15}$ was measured by a portable calorimeter at each point.

Sequential Gaussian simulation (sGs) using the sGsim program [50] was used to construct spatial distribution maps of $\mathrm{CO}_{2},{ }^{4} \mathrm{He}$, and heat fluxes. The sGs procedure allowed us to interpolate the different parameters at a nonsampled area between the sampling points and obtain the uncertainty of emissions. Emission of the entire area of study was estimated using these maps.

\section{Results and Discussion}

4.1. $\mathrm{CO}_{2}$ Fluxes and Isotopic Signatures. Diffuse $\mathrm{CO}_{2}$ efflux values ranged from below detection to $10,650 \mathrm{~g} \mathrm{~m}^{-2} \mathrm{~d}^{-1}$ with an average value of $879 \mathrm{~g} \mathrm{~m}^{-2} \mathrm{~d}^{-1}$. The spatially interpolated total diffuse $\mathrm{CO}_{2}$ output released from the summit cone of Teide volcano was calculated as $211 \pm 20 \mathrm{t} \mathrm{d}^{-1}$. Similar results were obtained by Pérez et al. [37]; an emission value of $180 \pm 21$ was calculated for the 2009 survey for an area of $0.11 \mathrm{~km}^{2}$.

The diffuse $\mathrm{CO}_{2}$ emission map (Figure 3) shows higher values located inside the crater, along the crater rim mainly close to the fumarolic area and towards the north and north-east flanks. The areas with higher $\mathrm{CO}_{2}$ efflux values also show relatively high temperatures and appear correlated to hydrothermal alteration at the surface, suggesting a mainly advective degasification mechanism governing the gas emission regime at the study area. The north and north-east anomalies are probably related to radial fissures propagated from the volcanic axis [37]. Lower values are observed at other sectors of the flanks of the cone.

The total diffuse $\mathrm{CO}_{2}$ output is comparable with the $219 \pm 36 \mathrm{t} \mathrm{d}^{-1}$ released by Pico do Fogo volcano, Cape Verde, a similar volcanic system in a similar volcano-tectonic environment, measured during a survey in February 2010 [21].

Figure 4 summarizes the $\mathrm{CO}_{2}$ isotopic composition and indicates that most of the analyzed samples correspond to a deep-seated source of $\mathrm{CO}_{2}$, with different degrees of atmospheric contributions. The heaviest $\delta^{13} \mathrm{C}\left(\mathrm{CO}_{2}\right)$ values, indicatives of deep-seated $\mathrm{CO}_{2}$, were measured in soil gases in and around the summit crater, where fumarolic activity and thermal anomalies occur. The contribution of biogenic $\mathrm{CO}_{2}$ can be considered negligible, which is consistent with the very limited vegetation and its related biological activity in the summit cone of Teide volcano.

4.2. ${ }^{4} \mathrm{He}$ Emission. The total output of ${ }^{4} \mathrm{He}$ from the studied area was estimated in $1.06 \pm 0.2 \mathrm{~kg} \mathrm{~d}^{-1}\left(265.15 \mathrm{~mol} \mathrm{~d}^{-1}\right)$ with the highest values observed where fumarolic activity is present, along the crater rim, and towards the north and northeast flanks, coinciding with the highest temperature and $\mathrm{CO}_{2}$ efflux values measured (Figure 5). The average value of the convective component exceeded the average value of the diffusive component by almost an order of magnitude (4.2 vs. $0.44 \mathrm{mg} \mathrm{m}^{-2} \mathrm{~d}^{-1}$, respectively). For this reason, we can assume that most of the diffuse gas emission from the summit cone of Teide volcano is governed by convection.

Similar studies carried out in other volcanic systems of the Canary Islands have taken into account only the diffusive component due to the lack of geothermal anomalies in the surface environment of the study areas. Padrón et al. 


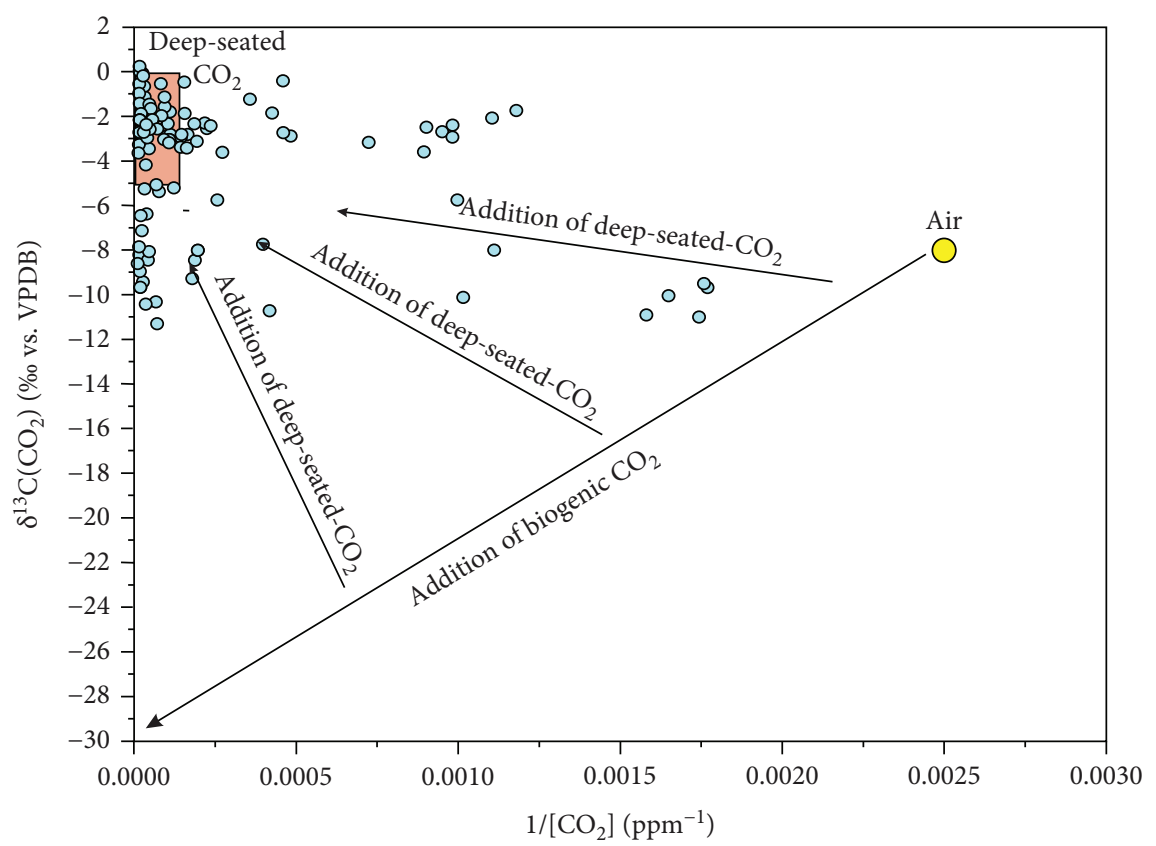

Figure 4: A plot of ${ }^{13} \delta \mathrm{C}\left(\mathrm{CO}_{2}\right)$ versus $1 /\left[\mathrm{CO}_{2}\right]\left(\mathrm{ppmV}^{-1}\right)$ data from the Teide summit cone and crater. This figure depicts three possible geochemical reservoirs: air, characterized by a $\delta^{13} \mathrm{C}\left(\mathrm{CO}_{2}\right)=-8 \%$ and $\left[\mathrm{CO}_{2}\right]=0.04 \%$, deep-seated $\mathrm{CO}_{2}$ with $\delta^{13} \mathrm{C}\left(\mathrm{CO}_{2}\right)=-3.1 \%$ and $[\mathrm{C}$ $\left.\mathrm{O}_{2}\right]=100 \%$, and biogenic $\mathrm{CO}_{2}$ with $\delta^{13} \mathrm{C}\left(\mathrm{CO}_{2}\right)=-27.5 \%$ and $\left[\mathrm{CO}_{2}\right]=100 \%$. Mixing trend between biogenic, air-derived, and deep-seated $\mathrm{CO}_{2}$ is represented by straight lines.

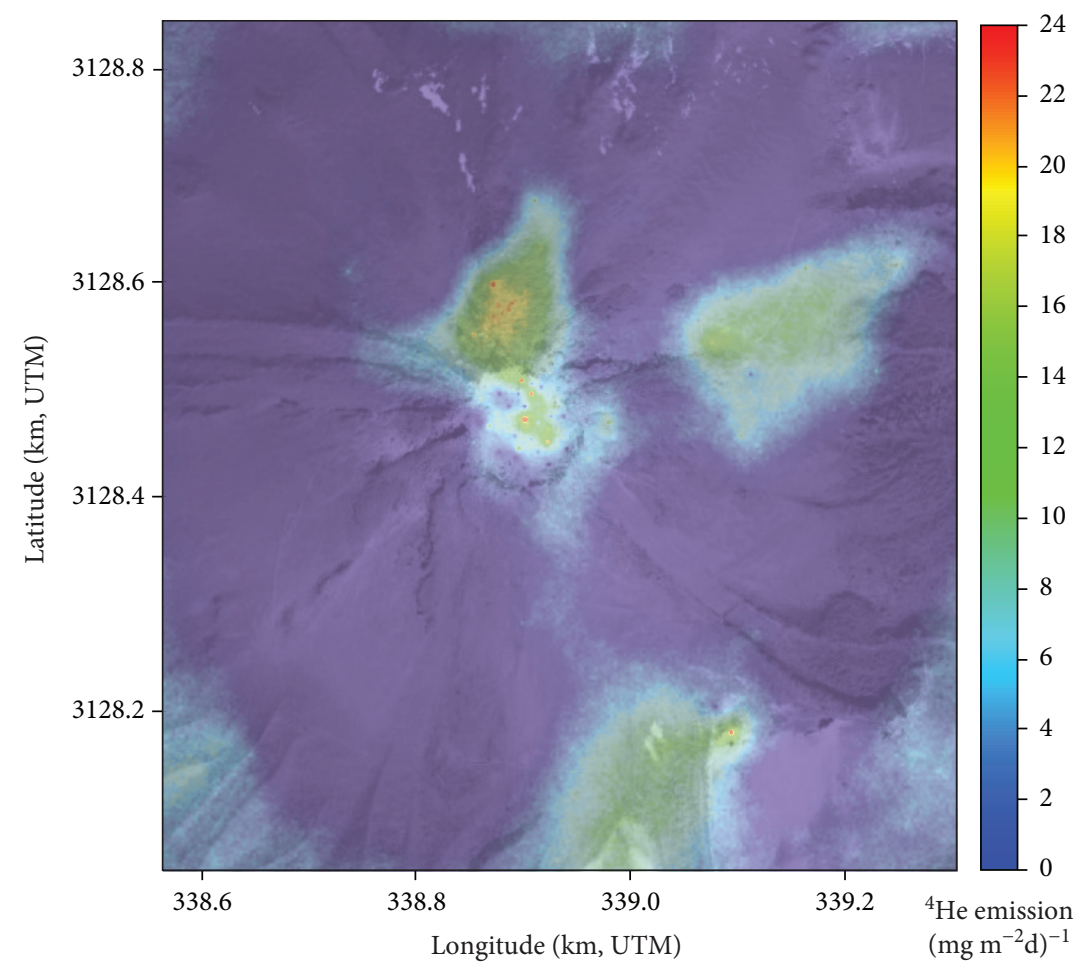

Figure 5: Diffuse ${ }^{4} \mathrm{He}$ emission map for the summit cone and crater of Teide volcano.

[51] estimate a ${ }^{4} \mathrm{He}$ emission between 15 and $38 \mathrm{~kg} \mathrm{~d}^{-1}$ from Cumbre Vieja volcano (La Palma) for an area of $220 \mathrm{~km}^{2}$. Padrón et al. [7] observed an increase in the diffusive component of ${ }^{4} \mathrm{He}$ emission from 9 to $38 \mathrm{~kg} \mathrm{~d}^{-1}$ of the whole $\mathrm{El}$
Hierro island $\left(278 \mathrm{~km}^{2}\right)$ prior to and during the $2011-2012$ submarine eruption that took place $2 \mathrm{~km}$ off the southern coast of the island. In the case of the summit cone of Teide, with an area of $0.5 \mathrm{~km}^{2}$, the normalized ${ }^{4} \mathrm{He}$ emission rate is 
TABLE 1: Outlet temperature, chemical, and isotopic composition of fumarolic gases from the summit crater of Teide volcano.

\begin{tabular}{lcccccc}
\hline & $T\left({ }^{\circ} \mathrm{C}\right)$ & ${ }^{4} \mathrm{He} /{ }^{20} \mathrm{Ne}$ & ${ }^{3} \mathrm{He} /{ }^{4} \mathrm{He}\left(R / R_{A}\right)$ & $\delta^{13} \mathrm{C}_{-} \mathrm{CO}_{2}(\%)$ & $\mathrm{CO}_{2}(\%)$ & $\mathrm{Gas}$ steam \\
\hline Teide fumarole & 83.3 & 33.613 & $6.723 \pm 0.056$ & $-3.13 \pm 0.01$ & 98.15 & 0.251 \\
\hline
\end{tabular}

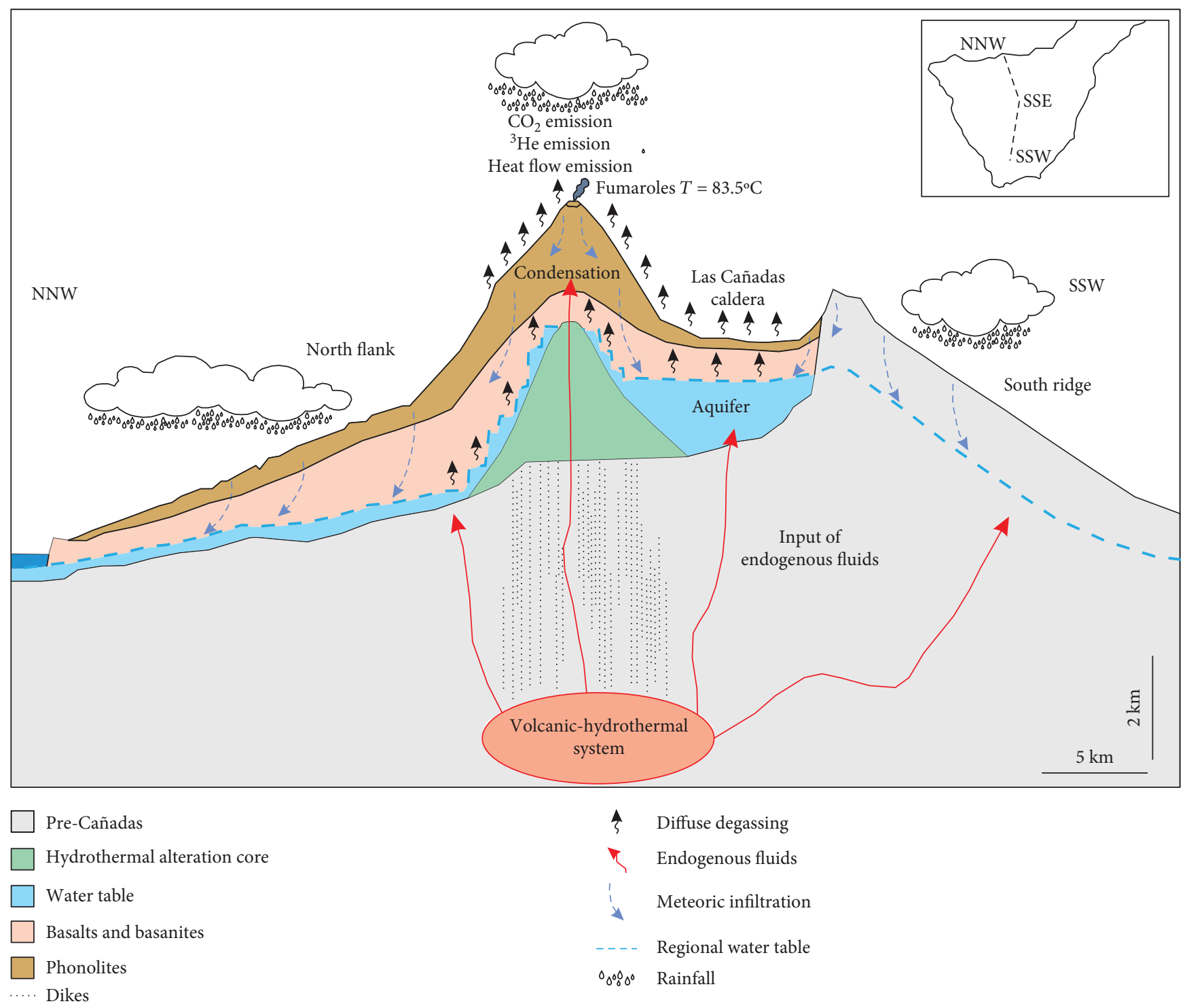

FIGURE 6: Hydrogeological model of Las Cañadas aquifer in the island of Tenerife. Fluid transport from the volcanic-hydrothermal system to the atmosphere is shown. Modified from Marrero-Díaz et al. [55].

$2.12 \mathrm{~kg} \mathrm{~km}^{-2} \mathrm{~d}^{-1}$, which represents a much higher value than that calculated for Cumbre Vieja and El Hierro (0.17 and $0.14 \mathrm{~kg} \mathrm{~km}^{-2} \mathrm{~d}^{-1}$, respectively).

The summit cone of Teide value for ${ }^{4} \mathrm{He}$ is comparable to Pico do Fogo volcano in Cape Verde. Dionis et al. [21] estimated a helium emission of $4.1 \mathrm{~kg} \mathrm{~d}^{-1}$ from the crater that has an area of $0.142 \mathrm{~km}^{2}$ by considering a pure convective emission and a normalized emission rate of $28 \mathrm{~kg} \mathrm{~km}^{-2} \mathrm{~d}^{-1}$. It is worth noting that Pico do Fogo volcano has experienced a higher eruptive activity in the historical times (last 500 years) than Teide. This observation might suggest a more general relationship between ${ }^{4} \mathrm{He}$ emission and volcanic activity than that demonstrated at the scale of the Cape Verde archipelago by Dionis et al. [21] using $\mathrm{CO}_{2}$ and ${ }^{3} \mathrm{He}$ emission.

4.3. ${ }^{3} \mathrm{He}$ Emission. Chemical and isotopic composition of fumarolic gases from the summit crater of Teide volcano are summarized in Table 1.

Assuming that the ${ }^{3} \mathrm{He} /{ }^{4} \mathrm{He}$ ratio analyzed from the fumaroles is the same for the whole hydrothermal system, the calculated diffuse ${ }^{3} \mathrm{He}$ emission for the first assumption is $2.48 \times 10^{-3} \mathrm{~mol} \mathrm{~d}^{-1}\left(0.89 \mathrm{~mol} \mathrm{y}^{-1}\right)$. Nevertheless, because 


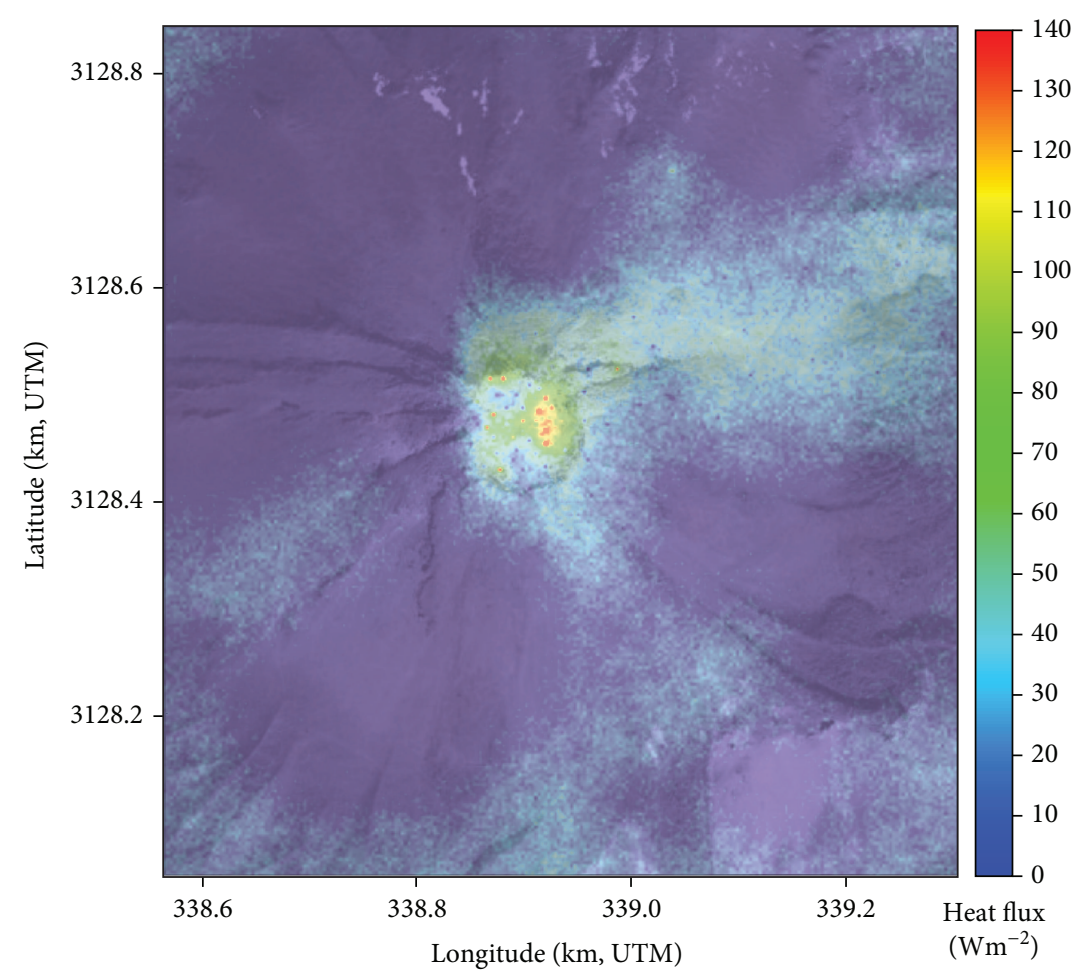

Figure 7: Heat flux emission map for the summit cone and crater of Teide volcano.

we have used the ${ }^{4} \mathrm{He}$ flux calculated before for our estimation, the ${ }^{3} \mathrm{He}$ emission could be overestimated because there must be some radiogenic ${ }^{4} \mathrm{He}$ from the crust. Anyway, that amount of ${ }^{4} \mathrm{He}$ from the crust is almost negligible for polygenetic volcanoes at oceanic islands as Tenerife [11]. For the second assumption, we use the $\mathrm{CO}_{2}$ flux calculated before because we assume that the ${ }^{3} \mathrm{He}$ flux is wholly derived from deep-seated source. The calculated ${ }^{3} \mathrm{He}$ emission is $9.69 \times 10^{-4} \mathrm{~mol} \mathrm{~d}^{-1}\left(0.35 \mathrm{~mol} \mathrm{y}^{-1}\right)$. In this case, some amount of $\mathrm{CO}_{2}$ derived from magma would be trapped by water in soil or groundwater during its ascent, so the true ${ }^{3} \mathrm{He}$ flux is underestimated and should be higher than the estimate. Marrero et al. [52] estimates through a $\mathrm{CO}_{2}$ mass balance that $17.5 \times 10^{8} \mathrm{~mol} \mathrm{y}^{-1}\left(211 \mathrm{t} \mathrm{d}^{-1}\right)$ of $\mathrm{CO}_{2}$ is discharged by the groundwaters of Las Cañadas aquifer $\left(144 \mathrm{~km}^{2}\right)$ (Figure 6). That means that there is a large amount of magmatic $\mathrm{CO}_{2}$ that is trapped in the aquifer during its ascent to the atmosphere, suggesting that ${ }^{3} \mathrm{He}$ emission calculated using the second assumption is clearly subestimated.

These summit-cone wide values are consistent with the crater-only value which was reported by Hernández et al. [53] to be $0.51 \mathrm{~mol} \mathrm{y}^{-1}$ (after correction of an error observed in the original calculation).

This work provides one more of the few values reported to date related to ${ }^{3} \mathrm{He}$ global emission, of which volcanic systems are highly significant. Other hot spot-type volcanic systems have shown similar (Piton de la Fournaise, La Réunion island, $1.1 \mathrm{~mol} \mathrm{y}^{-1}$ ) or higher emission values (Kilauea, Hawaii, 9-14 $\mathrm{mol}^{-1}$ ) [54], using fumarolic data. Other studies of soil ${ }^{3} \mathrm{He}$ emission in volcanic areas are rare. Padrón et al. [51] estimated a total output of ${ }^{3} \mathrm{He}$ in Cumbre Vieja volcano (La Palma, Canary Islands) of 0.6-0.7 mol y ${ }^{-1}$ considering a pure diffusive transport mechanism for an area of $220 \mathrm{~km}^{2}$.

4.4. Heat Flow. The computed thermal energy released by degassing of $1.26 \times 10^{12} \mathrm{~J} \mathrm{~d}^{-1}$ corresponds to a total heat flow of 2.21 MW. We obtained a value of $8.1 \pm 0.97 \mathrm{MW}$ using the Dawson method. In the interpolation map, the areas with the highest heat flow occurred at the fumarolic areas inside the crater, the crater rim, and the NE flank (Figure 7). The fumarolic area in the crater of Teide volcano has an average temperature of $83.5^{\circ} \mathrm{C}$ that it is constant since it began to register in 1993. The major component of these fumaroles is the water vapour, which originates from the vaporization of the rainfall water [33] followed by $\mathrm{CO}_{2}, \mathrm{~N}_{2}$, $\mathrm{H}_{2}, \mathrm{H}_{2} \mathrm{~S}, \mathrm{Ar}, \mathrm{CH}_{4}$, and $\mathrm{CO}$, a composition typical of hydrothermal fluids $[34,35]$. These data suggest that the fumarolic effluents are made by endogenous gases which cross the aquifer located somewhere in the postcaldera structure close to the surface [33]. At the same time, the heat flux in the crater of Teide volcano has been registered since 2009 and no significant changes have been detected. Most of the heat flow measured in Teide volcano is the result of the emitted heat by the phase change of water from gas to liquid in the condensation zone.

The difference between the heat emission calculations among two different methods is because the method proposed by Chiodini et al. [46] assumes that the $\mathrm{H}_{2} \mathrm{O} / \mathrm{CO}_{2}$ molar ratio measured in the fumarolic discharges is the same for the whole hydrothermal system. In this study, we are comparing areas with higher convective component at the 


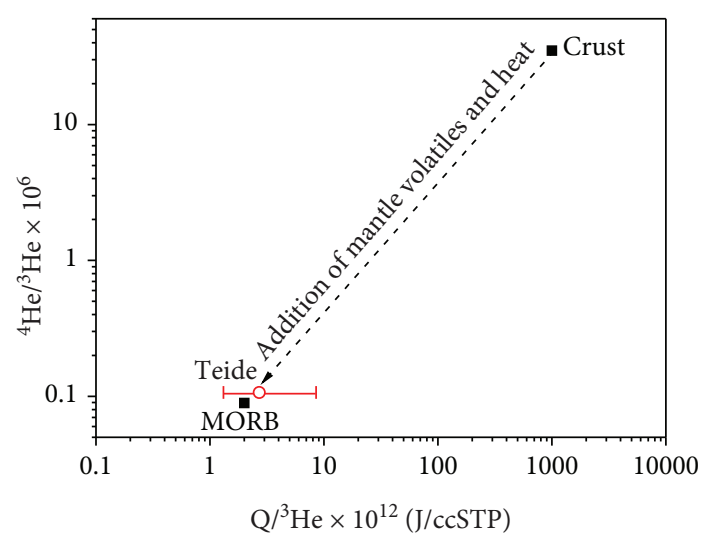

Figure 8: Schematic representation of the coherence between heat and helium.

crater with areas typified mainly by diffusive component at the flanks of the volcano, where there are no surface evidences of hydrothermal alteration.

To compare our data with other volcanic systems, Hernández et al. [3] estimated a total heat flow of 1.24 MW for the Hengill volcanic system; Chiodini et al. [2] reported the energy released by other volcanic areas as Campi Flegrei 100.8 MW, Ischia 40.1 MW, Vesuvio cone 16.6 MW, Vulcano crater $21 \mathrm{MW}$, and Comalito cinder cone 0.9 MW, and Dionis et al. [21] estimated a value of 10.3 MW released from the summit crater of Pico do Fogo volcano.

4.5. ${ }^{3}$ He/Heat Ratio. Following from the end-member assumptions used to calculate the ${ }^{3} \mathrm{He}$ and heat flux, we calculated a plausible ${ }^{3} \mathrm{He} /$ heat ratio range from $0.117 \times 10^{-12}$ to $0.764 \times 10^{-12} \mathrm{~cm}^{3} \mathrm{STP} \mathrm{J}^{-1}$, with an average value of $0.370 \times$ $10^{-12} \mathrm{~cm}^{3}$ STP J ${ }^{-1}$. This value is close to the $0.5 \times 10^{-12} \mathrm{~cm}^{3}$ STP J ${ }^{-1}$ calculated for the ${ }^{3} \mathrm{He} /$ heat ratio for hydrothermal activity from the upper mantle $[19,20]$. Figure 8 shows the relationship between heat and helium emissions, following the model of Kennedy et al. [17], which demonstrate that Teide volcano is a useful window to take measurements of volatiles and heat from the upper mantle of the Earth to the atmosphere. By extension, future studies that focus upon the temporal evolution of heat and volatile emission from Teide and similar windows to the mantle will improve understanding of mantle dynamics and the link between lithosphere and atmosphere.

\section{Conclusions}

Most of the volcano-hydrothermal fluid discharges occurring at the summit cone of Teide volcano occur in the crater area; yet, other important emission rates were measured along the north and north-east flanks. These extracrater emissions are suggestive of a strong structural control in the degassing process of Teide volcano. Given the prevalence of structural controls on the expression of volcanic systems worldwide, we can suggest that other important, yet not as obvious, emissions are likely to be encountered at other volcanic systems.
The estimated global volcanic emission of ${ }^{3} \mathrm{He}$ is $1250 \pm$ $250 \mathrm{~mol} \mathrm{y}^{-1}$ [54]. The contribution to this estimate emission obtained by Teide volcano in this work is about $0.62 \mathrm{~mol} \mathrm{y}^{-1}$, for an area of $0.5 \mathrm{~km}^{2}, 0.05 \%$ of the total global emission. This study provides the first estimation of ${ }^{3} \mathrm{He} /$ heat from the Teide volcanic system and supports theoretical estimates at a global scale. The calculation of flux supports the presence of an important mantle source of volatiles and heat to the atmosphere.

\section{Data Availability}

The raw geochemical data used to support the findings of this study are stored on servers at ITER and can be made available by reasonable arrangement with the corresponding author.

\section{Conflicts of Interest}

The authors declare that there is no conflict of interest regarding the publication of this paper.

\section{Acknowledgments}

This research was financially supported by the projects (i) VOLRISKMAC from MAC 2014-2020, (ii) TFvolcano and TFinnova from the Cabildo Insular de Tenerife (Spain), and (iii) the Ministry of Science and Innovation from Spanish Government from DI-16-08974. We thank Iván Cabrera Pérez and Matthew James Pankhurst for their contribution to improve the quality of this paper and also Teleférico del Teide and Teide National Park for their assistance during the field work and for the logistic support.

\section{Supplementary Materials}

Supplementary materials 1: ambient and soil temperatures and $\mathrm{CO}_{2}$ flux measured in each sampling site, and heat and ${ }^{4} \mathrm{He}$ fluxes calculated using the methodology described in the manuscript. Supplementary materials 2: data obtained from the analysis of the soil gases recollected in each sampling site. (Supplementary Materials)

\section{References}

[1] T. A. Mather, "Volcanoes and the environment: lessons for understanding Earth's past and future from studies of present-day volcanic emissions," Journal of Volcanology and Geothermal Research, vol. 304, pp. 160-179, 2015.

[2] G. Chiodini, D. Granieri, R. Avino, S. Caliro, A. Costa, and C. Werner, "Carbon dioxide diffuse degassing and estimation of heat release from volcanic and hydrothermal systems," Journal of Geophysical Research, vol. 110, no. B8, pp. 2156-2202, 2005.

[3] P. A. Hernández, N. M. Pérez, T. Fridriksson et al., "Diffuse volcanic degassing and thermal energy release from Hengill volcanic system, Iceland," Bulletin of Volcanology, vol. 74, no. 10, pp. 2435-2448, 2012.

[4] L. A. Pogorsky and G. S. Quirt, "Helium emanometry in exploring for hydrocarbons: part I," in Unconventional Methods in Exploration for Petroleum and Natural Gas IISouth, pp. 124-135, Methodist University Press, 1981. 
[5] D. M. Thomas and J. J. Naughton, "Helium/carbon dioxide ratios as premonitors of volcanic activity," Science, vol. 204, no. 4398, pp. 1195-1196, 1979.

[6] Y. Sano, Y. Nakamura, H. Wakita, A. Urabe, and T. Tominaga, "Helium-3 emission related to volcanic activity," Science, vol. 224, no. 4645, pp. 150-151, 1984.

[7] E. Padrón, N. M. Pérez, P. A. Hernández et al., "Diffusive helium emissions as a precursory sign of volcanic unrest," Geology, vol. 41, no. 5, pp. 539-542, 2013.

[8] W. B. Clarke, W. J. Jenkins, and Z. Top, "Determination of tritium by mass spectrometric measurement of ${ }^{3} \mathrm{He}$," International Journal of Applied Radiation and Isotopes, vol. 27, no. 9, pp. 515-522, 1976.

[9] D. W. Graham, "Noble gas isotope geochemistry of mid-ocean ridge and ocean island basalts: characterization of mantle source reservoirs," Reviews in Mineralogy and Geochemistry, vol. 47, no. 1, pp. 247-317, 2002.

[10] M. Sakamoto, Y. Sano, and H. Wakita, “3 $\mathrm{He} /{ }^{4} \mathrm{He}$ ratio distribution in and around the Hakone volcano," Geochemical Journal, vol. 26, no. 4, pp. 189-195, 1992.

[11] N. M. Pérez, S. Nakai, H. Wakita, P. A. Hernández, and J. M. Salazar, "Helium-3 emission in and around Teide volcano, Tenerife, Canary Islands, Spain," Geophysical Research Letters, vol. 23, no. 24, pp. 3531-3534, 1996.

[12] N. M. Pérez, S. Nakai, H. Wakita, Y. Sano, and S. N. Williams, ${ }^{13} \mathrm{He} /{ }^{4} \mathrm{He}$ isotopic ratios in volcanic-hydrothermal discharges from the Canary Islands, Spain: implications on the origin of the volcanic activity," Mineralogical Magazine, vol. 58A, no. 2, pp. 709-710, 1994.

[13] D. R. Hilton, C. G. Macpherson, and T. R. Elliot, "Helium isotope ratios in mafic phenocrysts and geothermal fluids from La Palma, the Canary Islands Spain: implications for HIMU mantle sources," Geochimica et Cosmochimica Acta, vol. 64, no. 12, pp. 2119-2132, 2000.

[14] J. M. D. Day and D. R. Hilton, "Origin of ${ }^{3} \mathrm{He} /{ }^{4} \mathrm{He}$ ratios in HIMU-type basalts constrained from Canary Island lavas," Earth and Planetary Science Letters, vol. 305, no. 1-2, pp. 226-234, 2011.

[15] T. Torgersen and W. J. Jenkins, "Helium isotopes in geothermal systems: Iceland, The Geysers, Raft River and Steamboat Springs," Geochimica et Cosmochimica Acta, vol. 46, no. 5, pp. 739-748, 1982.

[16] Y. Sano and H. Wakita, "Geographical distribution of ${ }^{3} \mathrm{He} /{ }^{4} \mathrm{He}$ ratios in Japan: implications for arc tectonics and incipient magmatism," Journal of Geophysical Research, vol. 90, no. B10, pp. 8729-8741, 1985.

[17] B. M. Kennedy, T. P. Fischer, and D. L. Shuster, "Heat and helium in geothermal systems," Twenty-Fifth Workshop on Geothermal Reservoir Engineering Stanford University, 2000, Stanford, CA, USA, January 2000, 2000.

[18] K. Umeda, Y. Sakagawa, A. Ninomiya, and K. Asamori, "Relationship between helium isotopes and heat flux from hot springs in a non-volcanic region, Kii Peninsula, southwest Japan," Geophysical Research Letters, vol. 34, no. 5, article L05310, 2007.

[19] J. E. Lupton, E. T. Baker, and G. J. Massoth, "Variable ${ }^{3} \mathrm{He} /$ heat ratios in submarine hydrothermal systems: evidence from two plumes over the Juan de Fuca ridge," Nature, vol. 337, no. 6203, pp. 161-164, 1989.

[20] H. Elderfield and A. Schultz, "Mid-ocean ridge hydrothermal fluxes and the chemical composition of the ocean," Annual
Review of Earth and Planetary Sciences, vol. 24, no. 1, pp. 191-224, 1996.

[21] S. M. Dionis, G. Melián, F. Rodríguez et al., "Diffuse volcanic gas emission and thermal energy release from the summit crater of Pico do Fogo, Cape Verde," Bulletin of Volcanology, vol. 77, no. 2, p. 10, 2015

[22] T. Fridriksson, B. R. Kristjánsson, H. Ármannsson, E. Margrétardóttir, S. Ólafsdóttir, and G. Chiodini, " $\mathrm{CO}_{2}$ emissions and heat flow through soil, fumaroles and steam heated mud pools at the Reykjanes geothermal area, SW Iceland," Applied Geochemistry, vol. 21, no. 9, pp. 1551-1569, 2006.

[23] J. C. Carracedo, E. R. Badiola, H. Guillou et al., "Eruptive and structural history of Teide volcano and rift zones of Tenerife, Canary Islands," Geological Society of America Bulletin, vol. 119, no. 9-10, pp. 1027-1051, 2007.

[24] F. Anguita and F. Hernán, "The Canary Islands origin: a unifying model," Journal of Volcanology and Geothermal Research, vol. 103, no. 1-4, pp. 1-26, 2000.

[25] H. Guillou, J. C. Carracedo, R. Paris, and F. J. Pérez Torrado, "Implications for the early shield-stage evolution of Tenerife from K/Ar ages and magnetic stratigraphy," Earth and Planetary Science Letters, vol. 222, no. 2, pp. 599-614, 2004.

[26] E. Ancochea, J. M. Fuster, E. Ibarrola et al., "Volcanic evolution of the island of Tenerife (Canary Islands) in the light of new K.Ar data," Journal of Volcanology and Geothermal Research, vol. 44, no. 3-4, pp. 231-249, 1990.

[27] J. Martí, J. Mitjavila, and V. Araña, "Stratigraphy, structure and geochronology of the Las Cañadas caldera (Tenerife, Canary Islands)," Geological Magazine, vol. 131, no. 6, pp. 715-727, 1994.

[28] J. Martí and A. Gudmundsson, "The Las Cañadas caldera (Tenerife, Canary Islands); an overlapping collapse caldera generated by magma-chamber migration," Journal of Volcanology and Geothermal Research, vol. 103, no. 1-4, pp. 161$173,2000$.

[29] M. J. Huertas, N. O. Arnaud, E. Ancochea, J. M. Cantagrel, and J. M. Fúster, ${ }^{440} \mathrm{Ar} /{ }^{39} \mathrm{Ar}$ stratigraphy of pyroclastic units from the Cañadas Volcanic edifice (Tenerife, Canary Islands) and their bearing on the structural evolution," Journal of Volcanology and Geothermal Research, vol. 115, no. 3-4, pp. 351-365, 2002.

[30] J. Martí, M. Hurlimann, G. J. Ablay, and A. Gudmundsson, "Vertical and lateral collapses on Tenerife (Canary Islands) and other volcanic ocean islands," Geology, vol. 25, no. 10, pp. 879-882, 1997.

[31] J. Dóniz, C. Romero, E. Coello et al., "Morphological and statistical characterisation of recent mafic volcanism on Tenerife (Canary Islands, Spain)," Journal of Volcanology and Geothermal Research, vol. 173, no. 3-4, pp. 185-195, 2008.

[32] G. J. Ablay and J. Martí, "Stratigraphy, structure, and volcanic evolution of the Pico Teide-Pico Viejo formation, Tenerife, Canary Islands," Journal of Volcanology and Geothermal Research, vol. 103, no. 1-4, pp. 175-208, 2000.

[33] J. F. Albert-Beltrán, V. Araña, J. L. Diez, and A. Valentin, "Physical-chemical conditions of the Teide volcanic system (Tenerife, Canary Islands)," Journal of Volcanology and Geothermal Research, vol. 43, no. 1-4, pp. 321-332, 1990.

[34] N. M. Pérez, N. C. Sturchio, S. N. Williams, J. C. Carracedo, and J. Coello, "Geochemical characteristics of the volcanichydrothermal gases in Teide, Timafaya, Taburiente, and 
Teneguia volcanoes, Canary Islands, Spain," in Proceedings of the Scientific Sessions: III Geological Congress of Spain, Volume 1, pp. 463-467, Graficas Varona, Salamanca, 1992.

[35] G. Melián, F. Tassi, N. Pérez et al., “A magmatic source for fumaroles and diffuse degassing from the summit crater of Teide volcano (Tenerife, Canary Islands): a geochemical evidence for the 2004-2005 seismic-volcanic crisis," Bulletin of Volcanology, vol. 74, no. 6, pp. 1465-1483, 2012.

[36] T. Mori, P. A. Hernández, J. M. L. Salazar, N. M. Pérez, and K. Notsu, "An in situ method for measuring $\mathrm{CO}_{2}$ flux from volcanic-hydrothermal fumaroles," Chemical Geology, vol. 177, no. 1-2, pp. 85-99, 2001.

[37] N. M. Pérez, P. A. Hernández, E. Padrón et al., “An increasing trend of diffuse $\mathrm{CO}_{2}$ emission from Teide volcano (Tenerife, Canary Islands): geochemical evidence of magma degassing episodes," Journal of the Geological Society, vol. 170, no. 4, pp. 585-592, 2013.

[38] K. J. Parkinson, "An improved method for measuring soil respiration in the field," Journal of Applied Ecology, vol. 18, no. 1, pp. 221-228, 1981.

[39] W. F. Giggenbach and R. L. Goguel, Collection and Analysis of Geothermal and Volcanic Water and Gas Discharges, Unpublished report, Chemistry Division, DSIR-Petone, New Zealand, 1989.

[40] H. Sumino, K. Nagao, and K. Notsu, "Highly sensitive and precise measurement of helium isotopes using a mass spectrometer with double collector system," Journal of the Mass Spectrometry Society of Japan, vol. 49, no. 2, pp. 61-68, 2001.

[41] J. Matsuda, T. Matsumoto, H. Sumino et al., "The ${ }^{3} \mathrm{He} /{ }^{4} \mathrm{He}$ ratio of the new internal He standard of Japan (HESJ)," Geochemical Journal, vol. 36, no. 2, pp. 191-195, 2002.

[42] H. Craig and J. E. Lupton, "Primordial neon, helium and hydrogen in oceanic basalts," Earth and Planetary Science Letters, vol. 31, no. 3, pp. 369-385, 1976.

[43] G. Etiope and G. Martinelli, "Migration of carrier and trace gases in the geosphere: an overview," Physics of the Earth and Planetary Interiors, vol. 129, no. 3-4, pp. 185-204, 2002.

[44] M. G. Schaap and I. Lebron, "Using microscope observations of thin sections to estimate soil permeability with the Kozeny-Carman equation," Journal of Hydrology, vol. 251, no. 3-4, pp. 186-201, 2001.

[45] M. L. Carapezza and D. Granieri, " $\mathrm{CO}_{2}$ soil flux at Vulcano (Italy): comparison between active and passive methods," Applied Geochemistry, vol. 19, no. 1, pp. 73-88, 2004.

[46] G. Chiodini, F. Frondini, C. Cardellini, D. Granieri, L. Marini, and G. Ventura, " $\mathrm{CO}_{2}$ degassing and energy release at Solfatara volcano, Campi Flegrei, Italy," Journal of Geophysical Research, vol. 106, no. B8, pp. 16213-16221, 2001.

[47] F. Frondini, G. Chiodini, S. Caliro, C. Cardellini, D. Granieri, and G. Ventura, "Diffuse $\mathrm{CO}_{2}$ degassing at Vesuvio, Italy," Bulletin of Volcanology, vol. 66, no. 7, pp. 642-651, 2004.

[48] J. H. Keenan, F. G. Keyes, P. G. Hill, and J. G. Moore, Steam Tables Thermodynamic Properties of Water Including Vapor, Liquid and Solid Phases. International edition metric units, Wiley, New York, NY, USA, 1969.

[49] G. B. Dawson, "The nature and assessment of heat flow from hydrothermal areas," New Zealand Journal of Geology and Geophysics, vol. 7, no. 1, pp. 155-171, 1964.

[50] C. Deutsch and A. Journel, GSLIB: Geostatistical Software Library and Users Guide, Oxford University Press, New York, NY, USA, 2nd edition, 1998.
[51] E. Padrón, N. M. Pérez, P. A. Hernández et al., "Helium emission at cumbre Vieja volcano, La Palma, Canary Islands," Chemical Geology, vol. 312-313, pp. 138-147, 2012.

[52] R. Marrero, D. L. López, P. A. Hernández, and N. M. Pérez, "Carbon dioxide discharged through the las Cañadas aquifer, Tenerife, Canary Islands," Pure and Applied Geophysics, vol. 165 , no. 1, pp. 147-172, 2008.

[53] P. A. Hernández, N. M. Pérez, J. M. Salazar, S. Nakai, K. Notsu, and H. Wakita, "Diffuse emission of carbon dioxide, methane and helium-3 from Teide volcano, Tenerife, Canary Islands," Geophysical Research Letters, vol. 25, no. 17, pp. 3311-3314, 1998.

[54] P. Allard, "Global emissions of Helium-3 by subaerial volcanism," Geophysical Research Letters, vol. 19, no. 14, pp. 1479-1481, 1992.

[55] R. Marrero-Díaz, D. López, N. M. Pérez et al., “Carbon dioxide and helium dissolved gases in groundwater at Central Tenerife Island, Canary Islands: chemical and isotopic characterization," Bulletin of Volcanology, vol. 77, no. 10, p. 86, 2015. 

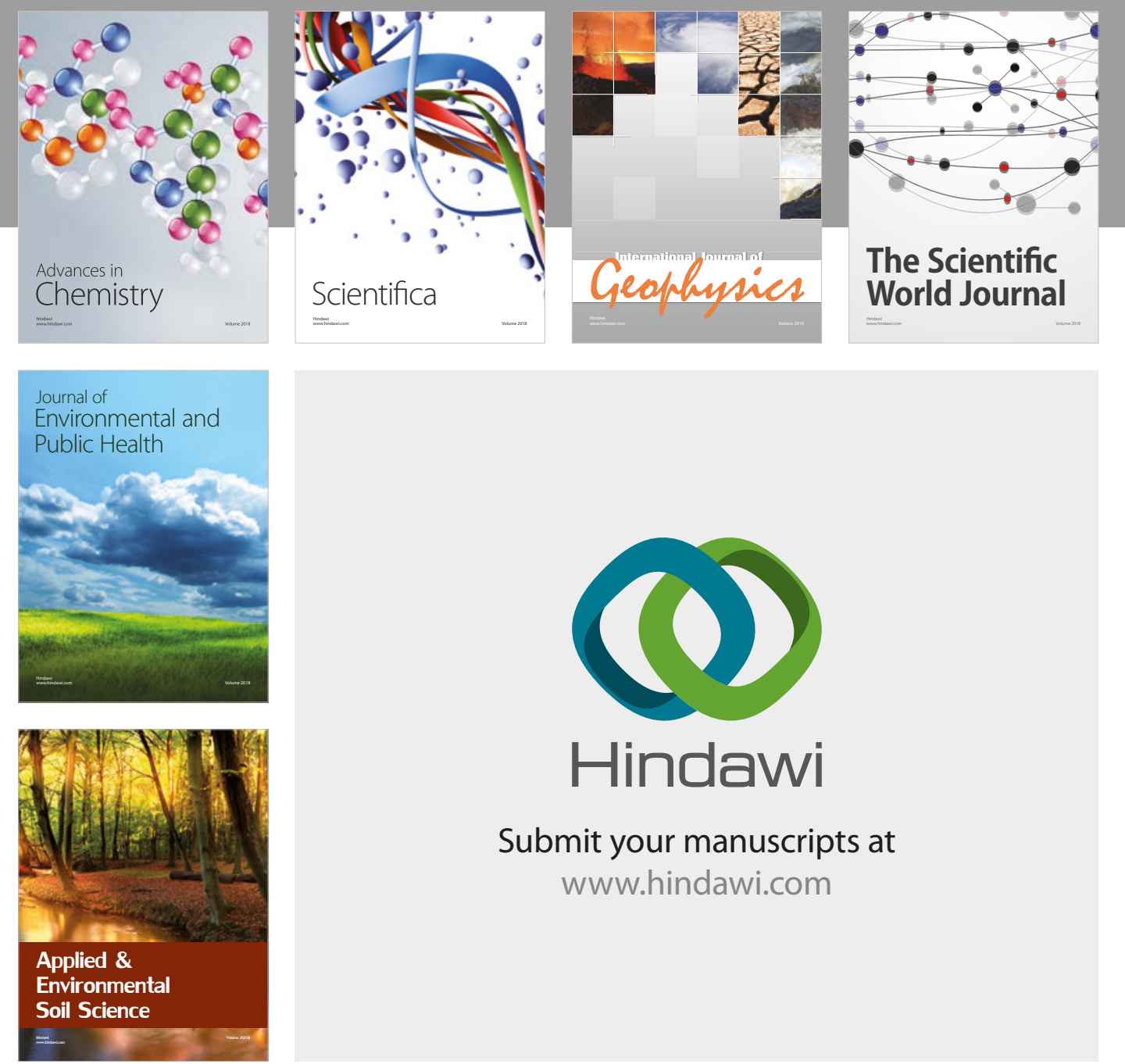

The Scientific

\section{World Journal}
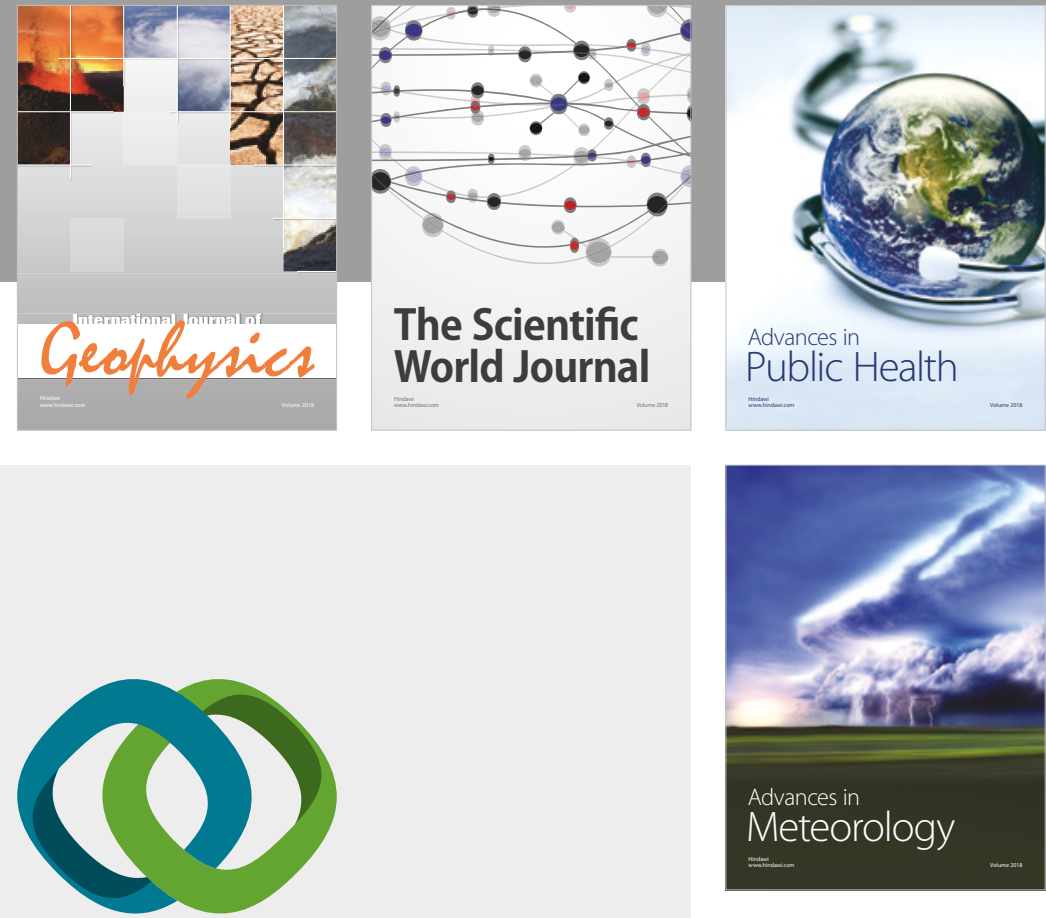

Advan

Public Health

\section{Hindawi}

Submit your manuscripts at

www.hindawi.com
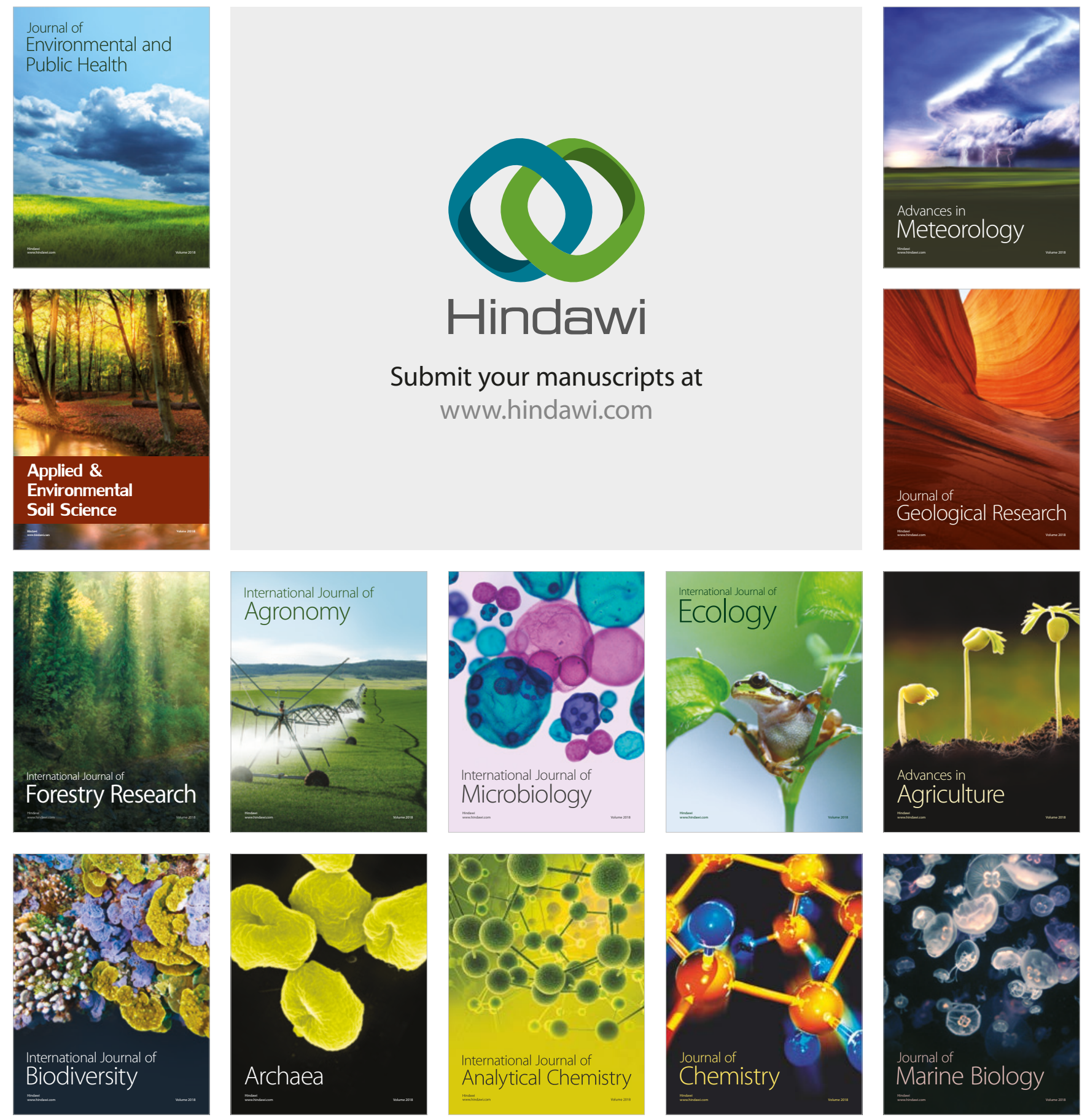